\title{
WERONIKA SOLKIEWICZ
}

Uniwersytet w Białymstoku

e-mail: wsolkiewicz@wp.pl

\section{Ograniczenia zasady wolności pracy}

\section{Freedom of work principle and how it is restricted}

Streszczenie. Zasada wolności pracy została uregulowana w art. 65 Konstytucji oraz art. 10 i 11 Kodeksu pracy. W niniejszym artykule analizie poddano liczne ograniczenia tej zasady. Celem opracowania jest rozważenie, czy w związku z tymi ograniczeniami rzeczywiście istnieje wolność pracy oraz wykazanie, że ze względu na ogromną rolę pracy w życiu człowieka, niezwykle ważna jest odpowiednia, przemyślana regulacja dotycząca zasady wolności pracy.

Summary. Freedom of work principle is regulated in articles 65 of polish Constitution and article 10 and 11 of The Labor Code. In this article, restrictions of this principle are taken into analysis. The aim of this publication is to consider if freedom of work actually exists in conjunction with restrictions. Moreover, it is indicated that due to a huge role of work in people`s lives, it is exceedingly important to create relevant, deliberate regulations of the freedom of work principle.

Słowa kluczowe: zasada wolności pracy; ograniczenia.

Key words: freedom of work principle; restrictions.

\section{Pojęcie i rola pracy}

Pojęcie pracy jest różnie definiowane w naukach, co oznacza, że ma ono interdyscyplinarny charakter. Jest to bez wątpienia termin wieloznaczny. Według T. Nowackiego „pojęcie pracy cieszy się wieloma definicjami, formułowanymi z różnych stanowisk. Poszczególne nauki posługują się innymi definicjami. W różnych naukach ukształtowały się inne pojęcia pracy, choć przecież wszystkie one oznaczone są tym samym terminem" ${ }^{\text {. }}$ W znaczeniu potocznym praca przedstawiana jest jako „celowa działalność człowieka, połączona z wysiłkiem

\footnotetext{
${ }^{1}$ I. Oleksa, Praca jako wartość społeczna, „Scientific Bulletin of Chełm - Section of Pedagogy”, Chełm 2012, s. 13.
} 
fizycznym, zmierzająca do przekształcenia rzeczywistości przyrodniczej i społecznej dla potrzeb własnych i potrzeb społeczeństwa"2.

W tym opracowaniu skupię się jednak tylko na definicji pracy $\mathrm{w}$ rozumieniu konstytucyjnym i prawa pracy. Należy zaznaczyć, że nie wolno ograniczać interpretacji konstytucyjnej wolności pracy (rozumianej zgodnie z art. 65 Konstytucji ${ }^{3}$ jako zapewnienie każdemu wolność wyboru zawodu oraz wyboru miejsca pracy, a ponadto ustanowienie zakazu pracy przymusowej), do stosunku pracy w ujęciu prawa pracy. Pojęcie pracy powinno być rozumiane tu w sposób socjologiczny jako „każda forma aktywności zawodowej, polegająca na świadczeniu pracy na rzecz innego podmiotu, która stanowi podstawowe źródło utrzymania świadczącego pracę i jego najbliższych"4. Poza pracą świadczoną na podstawie umowy o pracę, powołania, wyboru, mianowania lub spółdzielczej umowy o pracę (zgodnie z przepisami kodeksu pracy), wyróżnia się też tzw. zatrudnienie niepracownicze typu cywilnego (np. na podstawie umowy zlecenia, umowy o dzieło), administracyjnoprawne (np. policjanci), ustrojowe (np. pełnienie funkcji przez posła), a także penalne (np. w ramach kary pozbawienia wolności $)^{5}$. W. Maciejko niejako polemizuje z wyżej przedstawioną definicją pracy. Jego zdaniem nie należy jej zawężać do pracy podejmowanej z przyczyn ekonomicznych w celu utrzymania siebie i rodziny. Zwraca on uwagę na to, iż np. kradzież może być także podejmowana w tym celu. Dlatego jego zdaniem czynność można uznać za pracę, jeśli jest moralnie akceptowalna, zgodna z przepisami prawa ${ }^{6}$. Wydaje się jednak, że Konstytucja nie posługuje się terminem pracy zgodnym z powyższą interpretacją. Ostatecznie należy stwierdzić, że przez pracę w rozumieniu Konstytucji uznaje się pracę w ujęciu kwestionowanym przez W. Maciejkę, czyli „wszelką pracę zarobkową na rzecz innego podmiotu bez względu na formalne zakwalifikowanie stosunku łączącego te podmioty"7.

Współcześnie rola pracy zdaje się rosnąć. Wpływa ona na życie człowieka na długo przed tym, gdy rozpocznie życie zawodowe. Dziecko, snując plany na przyszłość, bierze pod uwagę nie tylko życie rodzinne, ale także pracę. Od chwili rozpoczęcia kariery zawodowej to m.in. praca wyznacza pozycję człowieka w społeczeństwie, wpływa na status materialny,

\footnotetext{
${ }^{2}$ U. Bejma, Praca jako wartość w życiu człowieka. Wybrane aspekty, „Periodyk Naukowy Akademii Polonijnej” 2015, nr 4, s. 48-49.

${ }^{3}$ Konstytucja Rzeczypospolitej Polskiej z dnia 2 kwietnia 1997 r., Dz.U. z 2009 r., nr 78, poz. 483.

${ }^{4}$ P. Kuczma, Konstytucyjna wolność pracy, „Przegląd Prawa i Administracji” 2016, CVII, s. 322.

${ }^{5}$ L. Garlicki, Konstytucja Rzeczpospolitej Polskiej. Komentarz, Warszawa 2016, s. 643-644, a także: W. Sanetra, Prawo pracy: Zarys wykładu. Tom 1, Białystok 1994, s. 24-25.

${ }^{6} \mathrm{~W}$. Maciejko, O wolności pracy i równości pracujących, „Praca i Zabezpieczenie Społeczne” 2005, nr 1, s. 2-3.

${ }^{7}$ Wyrok TK z 23.02.2010 r., P 20/09, OTK-A 2010, Nr 34, poz. 191, Lex nr 559164.
} 
osobiste powodzenie, a poniekąd także na satysfakcję w innych aspektach życia, samorealizację i poczucie własnej wartości ${ }^{8}$. Praca ma podstawowe znaczenie w strefie socjalnej ze względu na to, iż w Polsce to właśnie praca, a nie kapitał, jest głównym źródłem dochodu większości obywateli oraz państwa. Zatem bezrobocie i brak rzeczywistych zabezpieczeń społecznych jest ogromnym problemem, powodującym niepewność i konflikty społeczne ${ }^{9}$. Praca może niestety prowadzić też do zaburzeń osobowości pracownika, ze względu na to, że pracodawca nie przestrzega jego praw, wyzyskuje (wykorzystuje) go ${ }^{10}$. Stąd, ze względu na to, jaką rolę odgrywa praca w życiu człowieka, niezwykle ważna jest odpowiednia, przemyślana regulacja prawna jej dotycząca. Istotną rolę w tym zakresie zdaje się odgrywać zasada wolności pracy. Potwierdzają to niejako słowa Jana Pawła II, który uważał, że praca wpływa na rozwój człowieka, ale aby się tak stało, każdy powinien ją sobie wybierać sam, zgodnie ze swoimi preferencjami i potrzebami. „Nigdy więcej praca przeciw człowiekowi, ale zawsze praca (...) w służbie człowieka"11.

\section{Zasada wolności pracy w polskim porządku prawnym}

Z uwagi na art. 9 Konstytucji, zgodnie z którym Rzeczpospolita Polska przestrzega wiążącego ją prawa międzynarodowego, należy brać je pod uwagę na etapie interpretacji zasady wolności pracy. Istnieje wiele aktów prawa międzynarodowego, których zobowiązana jest przestrzegać Rzeczpospolita Polska. Przykładem takiego aktu jest Międzynarodowy Pakt Praw Gospodarczych, Społecznych i Kulturalnych Organizacji Narodów Zjednoczonych z 1966 r. ${ }^{12}$ ratyfikowany przez Polskę w 1977 r. Jednakże celem niniejszego opracowania nie jest omówienie wiążących przepisów prawa międzynarodowego dotyczących tego zagadnienia, dlatego szczególną uwagę zwrócę na uregulowania polskie, które jednocześnie pozostają w zgodności z wspomnianymi przepisami.

Jak już wspomniano, zgodnie z art. 65 Konstytucji każdemu zapewnia się wolność wyboru zawodu oraz wyboru miejsca pracy, a ponadto ustanawia zakaz pracy przymusowej ${ }^{13}$. Trybunał Konstytucyjny w wyroku z 02.06.1999 r. wskazał, że wolność pracy „oznacza nie tylko brak przymusu, ale również brak ograniczeń, polegających na uniemożliwieniu podmiotom prawnym wykonywania określonego zawodu, czy zatrudnienia, nie przymuszając

\footnotetext{
${ }^{8}$ U. Bejma, Praca ..., s. $48-49$

${ }^{9}$ P. Kuczma, Konstytucyjna ..., s. 309

${ }^{10}$ A. Zwoliński, Praca i płaca jako temat nauczania Kościoła, „Studia Socialia Cracoviensia” 2013, nr 1, s. 32.

${ }^{11}$ Jan Paweł II, Przemówienie podczas 68 sesji Międzynarodowej Organizacji Pracy. Genewa 15 czerwca 1982 , w: Dokumenty nauki społecznej Kościoła, cz. 2, Rzym - Lublin 1996.

${ }^{12}$ Dz.U. z 1977 r. Nr 38, poz. 169.

${ }^{13}$ Dz.U. z 2009 r. Nr 78, poz. 483.
} 
ich jednocześnie do robienia czegoś innego" ${ }^{" 14}$.Warto w tym miejscu zwrócić uwagę na dwie postaci wolności pracy. Zasada wolności pracy w aspekcie pozytywnym zapewnia możliwość wyboru rodzaju pracy (aspekt kwalifikatywny), wyboru pracodawcy (aspekt podmiotowy), ale także decydowania o miejscu zatrudnienia (aspekt przestrzenny). Z kolei aspekt negatywny to zakaz nakładania obowiązku pracy. W związku z tym zasadę wolności pracy powinno się traktować w sposób integralny, biorąc pod uwagę łącznie aspekt pozytywny oraz negatywny ${ }^{15}$. Podmiotem wolności jest każdy człowiek (osoba fizyczna), która podejmuje pracę w Rzeczypospolitej Polskiej ${ }^{16}$. Zgodnie z art. 65 ust. 1 Konstytucji wyjątki od konstytucyjnej zasady określa ustawa. Ocena ograniczeń zasady wolności pracy jest dokonywana zgodnie z art. 31 ust. 3 Konstytucji, który stanowi, że muszą być one wprowadzone na podstawie ustawy i spełniać kryteria testu proporcjonalności ${ }^{17}$.

Do konstytucyjnej regulacji nawiązuje art. $10 \mathrm{kp}^{18}$, według którego każdy ma prawo do swobodnie wybranej pracy. Nikomu, z wyjątkiem przypadków określonych w ustawie, nie można zabronić wykonywania zawodu. Podkreśla się, że nie można jednak zabronić wyboru zawodu, gdyż jest to konstytucyjne prawo gwarantowane we wspomnianym już art. 65 ust. $1^{19}$. Rozwinięcie zasady wolności pracy stanowi art. $11 \mathrm{kp}$. Nawiązanie stosunku pracy oraz ustalenie warunków pracy i płacy wymaga zgodnego oświadczenia woli pracodawcy i pracownika. Zasada ta odnosi się do umownego stosunku pracy oraz stosunków pracy z wyboru, mianowania i powołania. Co prawda akty wyboru, mianowania i powołania są formalnie jednostronne, ale ze względu na zasadę wyrażoną w art. $11 \mathrm{kp}$, zgoda pracownika jest niezbędna do nawiązania stosunku pracy na tej podstawie ${ }^{20}$. Zasada swobody nawiązywania stosunku pracy dotyczy nie tylko pracownika, ale także pracodawcy, któremu co do zasady nie można nakazać nawiązania stosunku pracy, po jego stronie musi istnieć potrzeba zatrudnienia $\mathrm{i}$ korzystania $\mathrm{z}$ tej pracy za wynagrodzeniem ${ }^{21}$. Pomiędzy art. 65 ust. 1 a art. $10 \mathrm{kp}$ istnieją pewne odmienności, ale oba gwarantują swobodny wybór wykonywanej pracy ${ }^{22}$. Kodeksową normę od konstytucyjnej odróżnia przede wszystkim zakres adresatów. Zasada zapisana w Konstytucji skierowana jest do organów władzy

\footnotetext{
${ }^{14}$ Wyrok TK z 26.04.1999 r., K 33/98, OTK 1999, Nr 4, poz. 71, Lex nr 37316.

${ }^{15}$ Wyrok TK z 23.06.1999 r., K 30/98, OTK 1999, Nr 5, poz. 101, Lex nr 37396.

${ }^{16}$ Postanowienie TK z 09.04.2002 r., U 8/01, OTK-A 2001, Nr 2, poz. 25, Lex nr 54059.

17 A. Śledzińska-Simon, Wolność pracy, w: Realizacja i ochrona konstytucyjnych wolności i praw jednostki w polskim porzadku prawnym, Wrocław 2014, s. 589, jak również: wyrok TK z 19.10.1999, SK 4/99, OTK 1999, Nr 6, poz. 199, Lex nr 38260.

${ }^{18}$ Ustawa z dnia 26 czerwca 1974 r. - Kodeks pracy, tekst jedn.: Dz.U. z 2019 r. poz. 1040.

${ }^{19}$ T. Zieliński, G. Goździewicz, w: Kodeks pracy. Komentarz, red. L. Florek, Warszawa 2017, s. 99.

${ }^{20}$ T. Liszcz, Prawo pracy, Warszawa 2018, s. 240.

${ }^{21}$ Wyrok Sądu Apelacyjnego w Poznaniu z 1.08.2018 r., III AUa 640/17, Lex nr 2550847.

${ }^{22}$ B. Cudowski, Dodatkowe zatrudnienie, Białystok 2007, s. 17.
} 
publicznej, z kolei zasada wynikająca z kodeksu pracy jest skierowana do pracodawców oraz pracowników $^{23}$. Ponadto należy wskazać, iż kodeksowa zasada wolności pracy odnosi się do zatrudnienia $\mathrm{w}$ ramach stosunku pracy. Z kolei konstytucyjna zasada dotyczy także innych rodzajów zatrudnienia ${ }^{24}$.

Zasada wolności pracy - zarówno konstytucyjna, jak i kodeksowa - nie ma charakteru absolutnego. Istnieje możliwość wprowadzenia ustawowych ograniczeń tej zasady. Ponadto ustawy mogą dopuszczać ustalenie ograniczeń w umowie o pracę ${ }^{25}$ czy też w wyroku sądu wymierzającym środek karny $\mathrm{z}$ art. $41 \mathrm{kk}^{26} \mathrm{w}$ postaci zakazu zajmowania określonego stanowiska, wykonywania określonego zawodu lub prowadzenia określonej działalności gospodarczej. Przedmiotem niniejszego opracowania nie będą wszystkie ograniczenia zasady wolności pracy, ale jedynie te, które są najczęściej stosowane w praktyce.

\section{Ograniczenie zasady wolności pracy ze względu na wiek}

Zgodnie z art. 22 § 2 i 190 Kodeksu pracy pracownikiem może być osoba, która ukończyła 18 lat, a także młodociany, czyli osoba, która ukończyła 15 lat, ale nie ukończyła 18 lat. Jednakże istnieją pewne odrębności i obostrzenia związane z pracą młodocianych. Mogą być oni zatrudnieni tylko na podstawie umowy o pracę w celu przygotowania zawodowego lub na podstawie umowy o pracę przy wykonywaniu lekkich prac. Art. 65 ust. 3 Konstytucji RP ustanawia zakaz stałego zatrudniania dzieci do lat 16. Formy i charakter dopuszczalnego zatrudnienia określa ustawa. Art. $304^{5} \mathrm{kp}$ zezwala na wykonywanie pracy lub innych zajęć zarobkowych przez dziecko do ukończenia przez nie 16 roku życia, ale wyłącznie na rzecz podmiotu prowadzącego działalność kulturalną, artystyczną, sportową lub reklamową i wymaga uprzedniej zgody przedstawiciela ustawowego lub opiekuna tego dziecka, a także zezwolenia właściwego inspektora pracy.

Podkreślenia wymaga fakt, iż zgodnie z art. 103a ustawy z 1998 r. o emeryturach i rentach z Funduszu Ubezpieczeń Społecznych istnieje ograniczenie wolności zatrudnienia osób, które przekroczyły pewien wiek - wiek umożliwiający przejście na emeryturę. Z dniem spełnienia ustawowych wymagań, osoba ubiegająca się o emeryturę uzyska prawo do niej, ale realizacja tego prawa nastąpi dopiero po rozwiązaniu stosunku pracy z pracodawcą, na rzecz którego wykonywała ją bezpośrednio przed dniem nabycia prawa do emerytury, ustalonym

\footnotetext{
${ }^{23}$ P. Kuczma, Konstytucyjna ..., s. 315.

${ }^{24}$ M. Gersdorf, w: M. Gersdorf, K. Rączka, M. Raczkowski, Kodeks pracy. Komentarz, Warszawa 2011, s. 49.

${ }^{25}$ L. Garlicki, Konstytucja ..., s. 648-649, a także: TK z 13.06.2000 r., K 15/99, OTK 2000, Nr 5, poz. 137, Lex nr 41205.

${ }^{26}$ Ustawa z dnia 6 czerwca 1997 r. - Kodeks karny, tekst jedn.: Dz.U. z 2018, poz. 1600 ze zm.
} 
w decyzji organu rentowego. Inaczej prawo to ulegnie zawieszeniu do dnia rozwiązania stosunku pracy ${ }^{27}$. Celem takiej regulacji jest wyeliminowanie równoczesnego pobierania dwóch świadczeń, tj. wynagrodzenia za pracę i emerytury ${ }^{28}$. Po rozwiązaniu stosunku pracy może dojść do zawarcia nowej umowy i kontynuowania zatrudnienia u dotychczasowego pracodawcy za jego zgodą ${ }^{29}$. Mając na uwadze powyższe, trzeba zwrócić uwagę na utrudnienia przy ponownym zatrudnieniu w niektórych zawodach ze względu na specyfikę naboru, np. w przypadku urzędników państwowych, samorządowych czy korpusu służy cywilnej. Zwolnienie takiej osoby powoduje konieczność ponownego przeprowadzenia konkursu, co nie gwarantuje ponownego zatrudnienia ${ }^{30}$.

Ponadto należy zwrócić uwagę na kwestię ustalania górnej granicy wieku w procesie rekrutacji. Zgodnie $\mathrm{z}$ art. 6 pkt 1 lit. c dyrektywy Rady $\mathrm{z}$ dnia 27 listopada 2000 r. ustanawiającej ogólne warunki ramowe równego traktowania w zatrudnieniu i pracy Państwa Członkowskie mogą uznać, że odmienne traktowanie ze względu na wiek nie stanowi dyskryminacji (a tym samym nie zostanie naruszona zasada wolności pracy), jeżeli $\mathrm{w}$ ramach prawa krajowego zostanie to obiektywnie i racjonalnie uzasadnione zgodnym z przepisami celem, w szczególności celami polityki zatrudnienia, rynku pracy i kształcenia zawodowego, i jeżeli środki mające służyć realizacji tego celu są właściwe i konieczne ${ }^{31}$. Takie odmienne traktowanie może polegać między innymi właśnie na określeniu górnej granicy wieku przy rekrutacji, z uwzględnieniem wykształcenia wymaganego na danym stanowisku lub potrzeby racjonalnego okresu zatrudnienia przed przejściem na emeryturę. Trybunał Sprawiedliwości Unii Europejskiej kilkukrotnie orzekał w kwestii górnej granicy wieku w procesie rekrutacji. Tytułem przykładu, w sprawie Gorki Salaberria Sorando Trybunał $^{32}$ wskazał, że wykluczenie kandydatów mających więcej niż 35 lat z konkursu, którego celem jest nabór funkcjonariuszy policji, jest zgodne z prawem Unii, w szczególności nie narusza w/w dyrektywy. Jak zaznaczył Trybunał, charakter zadań, które są powierzane policjantom na stanowisku, którego dotyczy rekrutacja, wymaga posiadania szczególnej sprawności fizycznej. Niedostatki fizyczne w tym zawodzie mogą mieć poważne konsekwencje nie tylko dla samych funkcjonariuszy policji i dla osób trzecich, lecz także dla utrzymania porządku publicznego. Podobne rozstrzygnięcie zapadało także w sprawie Colina

\footnotetext{
${ }^{27}$ Tekst jedn.: Dz.U. z 2018 poz. 1270 ze zm.

${ }^{28}$ Wyrok Sądu Apelacyjnego w Łodzi z 12.10.2018 r., III AUa 108/18, Lex nr 2612064.

${ }^{29}$ Wyrok Sądu Najwyższego z 15.05.2018 r., I UK 118/17, Lex nr 2552682

${ }^{30}$ Wyrok Trybunału Konstytucyjnego z 13.11.2012 r., K 2/12, OTK-A 2012, Nr 10, poz. 121, Lex nr 1227132.

${ }^{31}$ Dz.U. UE L 303, 02/12/2000 P. 0016 - 0022.

${ }^{32}$ Wyrok Trybunału Sprawiedliwości Unii Europejskiej z 15.11.2016 r. (C-258/15), Dz.U. C 14 z 16.1.2017.
} 
$W_{\text {olfa }}^{33}$, gdzie ze względu na specyfikę pracy w Straży Pożarnej, za niedyskryminujące i nienaruszające zasady wolności pracy uznano ustalenie górnej granicy wieku 30 lat przy rekrutacji w technicznej służbie pożarniczej średniego szczebla. Wymóg posiadania określonego wieku służy zapewnieniu zdolności operacyjnej i dobrego funkcjonowania służb pożarniczych. Trybunał odmiennie rozstrzygnął sprawę Mario Vitala Péreza ${ }^{34}$. Za dyskryminujący, a zarazem naruszający zasadę wolności pracy uznano tu zapis w ogłoszeniu o konkursie, zgodnie z którym kandydaci na funkcjonariuszy policji lokalnej nie mogą przekraczać wieku 30 lat. W tym przypadku ustalenie granicy wieku 30 lat, biorąc pod uwagę zakres zadań na wskazanym stanowisku, jest nieproporcjonalne dla realizacji zgodnego z przepisami celu zapewnienia zdolności operacyjnej i dobrego funkcjonowania służb policyjnych.

\section{Obowiązek pracy}

Zasada wolności pracy doznaje ograniczeń także poprzez art. 65 ust. 2 Konstytucji, zgodnie z którym istnieje możliwość nałożenia obowiązku pracy przez ustawę. Regulacją wprowadzającą taki obowiązek jest m.in. ustawa z dnia 18 kwietnia 2002 r. o stanie klęski żywiołowej ${ }^{35}$ dotycząca trybu wprowadzenia i zniesienia stanu klęski żywiołowej, a także zasad działania organów władzy publicznej oraz zakresu ograniczeń wolności i praw człowieka i obywatela w czasie stanu klęski żywiołowej. Zgodnie z art. 22 ust. 1 pkt 3 tej ustawy jeżeli siły i środki, którymi dysponuje wójt (burmistrz, prezydent miasta), starosta lub wojewoda albo pełnomocnik, są niewystarczające, można wprowadzić obowiązek świadczeń osobistych i rzeczowych polegających na wykonywaniu określonych prac. Ponadto obowiązek pracy przewidziany jest w sytuacji odbywania kary pozbawienia wolności, ograniczenia wolności czy też osadzenia w areszcie tymczasowym. Wyżej wskazane przykłady jednocześnie uznaje się za prace jednostronnie wyznaczone ${ }^{36}$.

Wspomniany obowiązek wykonywania pracy przez osoby odbywające karę pozbawienia wolności został wprowadzony w art. $116 \S 1$ pkt 4 k.k.w ${ }^{37}$. Nie jest to jednak obowiązek bezwzględny, w k.k.w. zostały przewidziane zwolnienia od tego obowiązku, chociażby skazanych uznanych za niezdolnych do pracy ze względu na stan zdrowia

\footnotetext{
33 Wyrok Trybunału Sprawiedliwości Unii Europejskiej z dnia $12.01 .2010 \quad$ r. $\quad$ (C-229/08), Dz.U. C 63 z 13.3.2010.

${ }_{34}$ Wyrok Trybunału Sprawiedliwości Unii Europejskiej z dnia 13.12.2014 r. (C-416/13), Dz.U. C 16 z 19.1.2015.

${ }^{35}$ Tekst jedn.: Dz.U. z 2017 r. poz. 1897.

${ }^{36}$ J. Stelina, w: Prawo pracy, red. J. Stelina, Warszawa 2018, s. 8.

${ }^{37}$ Ustawa z dnia 6 czerwca 1997 r. - Kodeks karny wykonawczy, tekst jedn.: Dz.U. z 2019 poz. 676 ze zm.
} 
(art. $121 \S 6$ k.k.w). Kodeks karny wykonawczy przewiduje różne podstawy prawne zatrudnienia - skazanego zatrudnia się na podstawie skierowania do pracy albo umożliwia się skazanemu wykonywanie pracy zarobkowej w ramach umowy o pracę, umowy zlecenia, umowy o dzieło, umowy o pracę nakładczą lub na innej podstawie prawnej. Warto podkreślić, iż swoboda wyboru podstawy zatrudnienia jest znacząco ograniczona. Zatrudnienie skazanego następuje za zgodą i na warunkach określonych przez dyrektora zakładu karnego, a więc brak jest zgodnego oświadczenia woli pracodawcy i pracownika. Ponadto dyrektor jest uprawniony do cofnięcia zgody na zatrudnienie w przypadku, gdy skazany lub podmiot zatrudniający nie przestrzegają warunków zatrudnienia lub z przyczyn związanych z funkcjonowaniem zakładu karnego, a także $\mathrm{z}$ bezpieczeństwem skazanego. W art. $121 \S 10$ k.k.w. przewidziano kolejne ograniczenie w postaci możliwości wykonywania pracy wyłącznie na terenie zakładu karnego przez skazanego na karę dożywotniego pozbawienia wolności, odbywającego karę w zakładzie karnym typu zamkniętego. Należy jednak zaznaczyć, że zatrudnienie skazanego na podstawie skierowania do pracy nie zawsze musi się łączyć z obowiązkiem jej podjęcia. Przykładem takiej sytuacji jest zatrudnienie przy pracach szkodliwych dla zdrowia, przy których wymagana jest pisemna zgoda skazanego. Można z tego wyciągnąć wniosek, że w przypadku braku takiej zgody nie można zmusić skazanego do pracy.

\section{Zakaz zajmowania określonego stanowiska, wykonywania określonego zawodu lub prowadzenia działalności gospodarczej}

Istotną ingerencję $\mathrm{w}$ zasadę wolności pracy stanowi możliwość orzeczenia przez sąd na postawie art. 39 pkt $2 \mathrm{w}$ zw. z art. 41 kodeksu karnego środka karnego w postaci zakazu zajmowania określonego stanowiska, wykonywania określonego zawodu lub prowadzenia działalności gospodarczej, jeżeli sprawca nadużył przy popełnieniu przestępstwa stanowiska lub wykonywanego zawodu albo okazał, że dalsze zajmowanie stanowiska lub wykonywanie zawodu zagraża istotnym dobrom chronionym prawem ${ }^{38}$. Zakaz z art. $41 \S 1$ k.k. powinien być określony precyzyjnie i dotyczyć sfery aktywności życiowej oskarżonego, w której funkcjonował, dokonując przestępstwa. W tym miejscu należy podkreślić, że wskazany środek karny nie może doprowadzić do faktycznego pozbawienia możliwości podejmowania jakiejkolwiek aktywności zawodowej, nie może skutkować całkowitym wykluczeniem skazanego z rynku pracy ${ }^{39}$. Jeśli oskarżony, dopuszczając się przypisanego mu czynu, nie

\footnotetext{
${ }^{38}$ Tekst jedn.: Dz.U. z 2018, poz. 1600 ze zm.

${ }^{39}$ Wyrok Sądu Apelacyjnego w Katowicach z dnia 18.05.2017r., II AKa 88/17, Lex nr 2343405.
} 
wykonywał określonego zawodu, brak jest podstaw do orzeczenia zakazu wykonywania określonego zawodu ${ }^{40}$.

Równoważna w skutkach z wyżej wskazanym środkiem karnym jest decyzja starosty o cofnięciu diagnoście uprawnień do wykonywania badań technicznych wydana na podstawie art. 84 ust. 3 Prawa o ruchu drogowym ${ }^{41}$. Wydanie takiej decyzji jest możliwe, jeżeli w przypadku kontroli stwierdzono przeprowadzenie przez diagnostę badania technicznego niezgodnie z określonym zakresem i sposobem wykonania lub wydanie zaświadczenia albo dokonanie wpisu do dowodu rejestracyjnego pojazdu niezgodnie ze stanem faktycznym lub przepisami. Pociąga to za sobą niemożność wydania przez organ osobie zainteresowanej ponownego uprawnienia wcześniej niż po upływie 5 lat od dnia, w którym decyzja stała się ostateczna $^{42}$.

\section{Zakaz podejmowania działalności konkurencyjnej}

$\mathrm{W}$ piśmiennictwie istnieją pewne kontrowersje związane z umowami ograniczającymi zatrudnienie. Twierdzi się, że są one nieważne ze względu na sprzeczność z art. $10 \S 1 \mathrm{kp}{ }^{43}$. Jednakże przeważa stanowisko, zgodnie z którym pracownik ma prawo do dysponowania swoją wolnością i w związku z tym istnieje możliwość ustalania umownych ograniczeń ${ }^{44}$.

Kodeks pracy w art. $101^{1}$ i $101^{2}$ umożliwia umowne nałożenie na pracownika zakazu podejmowania działalności konkurencyjnej zarówno w czasie trwania, jak również po ustaniu stosunku pracy. Pracownik, którego obejmuje ten zakaz, nie może prowadzić konkurencyjnej działalności na własny rachunek oraz podejmować zatrudnienia na rzecz innego podmiotu prowadzącego taką działalność. Brak jest definicji legalnej działalności konkurencyjnej, W związku z tym, należy przyjąć za słuszne wnioski wynikające z orzecznictwa. W orzecznictwie Sądu Najwyższego za działalność konkurencyjną uznaje się aktywność przejawianą w tym samym lub takim samym zakresie przedmiotowym i skierowaną do tego samego kręgu odbiorców, pokrywająca się, chociażby częściowo, z zakresem działalności podstawowej lub ubocznej pracodawcy. Może dotyczyć działalności prowadzonej lub planowanej przez pracodawcę ${ }^{45}$. Należy wskazać, iż przy rozpatrywaniu możliwości ustanowienia zakazu podejmowania działalności konkurencyjnej po ustaniu stosunku pracy, powinna zaistnieć jeszcze jedna przesłanka - pracodawca i pracownik mają dostęp do

\footnotetext{
${ }^{40}$ Wyrok Sądu Apelacyjnego w Łodzi z dnia 27.11.2013 r., II AKa 65/13, Lex nr 1402878.

${ }^{41}$ Ustawa z dnia 20 czerwca 1997 r. Prawo o ruchu drogowym, tekst jedn.: Dz.U. z 2018 poz. 1990 ze zm.

${ }^{42}$ Wyrok Naczelnego Sądu Administracyjnego z dnia 31.08.2006 r., OSK 1151/05, Lex 275441.

${ }^{43}$ A. Sobczyk, w: Kodeks pracy. Komentarz, red. A. Sobczyk, Warszawa 2018, s. 38.

${ }^{44}$ B. Cudowski, Dodatkowe zatrudnienie ..., s. 17

${ }^{45}$ Wyrok SN z dnia 24.10.2006 r., II PK 39/06, Lex nr 309389.
} 
szczególnie ważnych informacji, których ujawnienie mogłoby narazić pracodawcę na szkodę. Pojęcie szczególnie ważnych informacji, których ujawnienie mogłoby narazić pracodawcę na szkodę nie zostało doprecyzowane w kodeksie pracy, jednak wskazuje się, że jego ocena nie zależy od kryteriów obiektywnych, lecz subiektywnego przekonania pracodawcy ${ }^{46}$.

Jak już zostało wspomniane, zakaz podejmowania działalności konkurencyjnej może być nałożony w umowie - pracownik nie musi się zgodzić na zawarcie takiej umowy. Oznacza to, że nie obowiązuje on z mocy samego prawa, ale z woli stron. W przypadku zakazu konkurencji w czasie trwania stosunku pracy kodeks pracy nie ustanawia obowiązku ustalenia ekwiwalentu czy odszkodowania na rzecz pracownika. Przyjmuje się jednak, że ustalenie w umowie ekwiwalentu jest możliwe. Z kolei w przypadku zakazu konkurencji obowiązującego po ustaniu stosunku pracy, pracownik uprawniony jest do odszkodowania, które zgodnie z art. $101^{2} \S 3$ nie może być niższe od 25\% wynagrodzenia otrzymanego przez pracownika przed ustaniem stosunku pracy przez okres odpowiadający okresowi obowiązywania zakazu konkurencji. Wskazuje się, że zakaz konkurencji ustanawiany jest $\mathrm{w}$ interesie pracodawcy ${ }^{47}$.

Istnieje pogląd, zgodnie z którym umowa o zakazie konkurencji nie jest wyjątkiem od zasady wolności pracy. Zgodnie z nim w/w przepisy stanowią jedynie o minimalnych standardach umów niejako w celu ochrony i zabezpieczenia finansowego pracownika ze strony pracodawcy ${ }^{48}$. Jednakże wydaje się, że z tym poglądem nie należy się jednak zgodzić. Mając na uwadze powyższe rozważania, należy przyjąć, że zakaz ten stanowi istotne ograniczenie zasady wolności pracy przez okres jego obowiązywania, a tym samym możliwości zarobkowych pracownika. Odszkodowanie ustalone w związku z zakazem obowiązującym po ustaniu stosunku pracy nie zawsze w pełni wynagrodzi powstrzymanie się od podjęcia działalności konkurencyjnej. Ponadto należy zwrócić uwagę na istniejącą linię orzeczniczą, zgodnie z którą świadczenie pracownika polegające na powstrzymaniu się od prowadzenia działalności konkurencyjnej wobec pracodawcy ogranicza w tym zakresie podstawową zasadę wolności pracy ${ }^{49}$.

\footnotetext{
${ }^{46}$ Wyrok SN z dnia 16.05.2001 r., II PKN 402/00, Lex nr 74886.

${ }^{47}$ Wyrok SA w Szczecinie z dnia 29.09.2016 r., III APa 2/16, Lex nr 2202540.

${ }^{48}$ A. Sobczyk, w: Kodeks pracy..., s. 38

${ }^{49}$ Wyrok SN z 12.04.2016 r., II PK 73/15, OSP 2017, Nr 6, poz. 17, Lex 2053636, a także: wyrok SN z 23.05.2014 r., II PK 273/13, Lex nr 1461235 oraz postanowienie SN z 6.09.2018 r., II PK 227/17, Lex nr 2549377.
} 


\section{Zawody zaufania publicznego}

"Zawód zaufania publicznego" to zawód polegający na obsłudze osobistych potrzeb ludzkich, wiążący się z przyjmowaniem informacji dotyczących życia osobistego i zorganizowany w sposób uzasadniający przekonanie społeczne o właściwym dla interesów jednostki wykorzystywaniu tych informacji przez świadczących usługi. Wykonywanie zawodu zaufania publicznego określane jest dodatkowo normami etyki zawodowej, szczególną treścią ślubowania, tradycją korporacji zawodowej czy szczególnym charakterem wykształcenia wyższego i uzyskanej specjalizacji (aplikacja) ${ }^{50}$. Osoby wykonujące zawód zaufania publicznego powinny swą pomoc świadczyć w sposób kompetentny, rzetelny i wiarygodny, mając na uwadze swoją osobistą odpowiedzialność za należyte wykonanie świadczenia na rzecz odbiorcy ${ }^{51}$. Zgodnie $\mathrm{z}$ art. 17 Konstytucji RP istnieje konieczność objęcia tych zawodów obowiązkiem przynależności do samorządu zawodowego.

Zgodnie $\mathrm{z}$ orzecznictwem Trybunału Konstytucyjnego treścią zasady wolności wykonywania zawodów zaufania publicznego jest stworzenie takiej sytuacji prawej, w której każdy będzie miał swobodny dostęp do wykonywania zawodu, uzależniony od talentu i kwalifikacji, rzeczywistą możliwość jego wykonywania, a także brak podporządkowania ${ }^{52}$. Podkreśla się, że ze względu na wykonywanie zadań o szczególnym charakterze z punktu widzenia zadań publicznych i z troski o realizację interesu publicznego, wymagane jest określenia przez ustawodawcę szczególnych ograniczeń w dostępie do zawodów zaufania publicznego. Związane jest to $\mathrm{z}$ koniecznością szczególnej ochrony odbiorców usług świadczonych $\mathrm{w}$ ramach tych zawodów. W piśmiennictwie zaznacza się, że weryfikacja przygotowania i naboru do zawodu nie mogą być pozostawione nieograniczonej swobodzie gry rynkowej ${ }^{53}$.

Przykładami zawodów zaufania publicznego są zawody adwokata, radcy prawnego, notariusza, lekarza i lekarza dentysty, architektów, inżynierów budownictwa czy doradców podatkowych.

\section{Inne ograniczenia zasady wolności pracy}

Poza ograniczeniami wskazanymi w punktach poprzednich istnieje także wiele innych ograniczeń zasady wolności pracy. Swoistym ograniczeniem swobody wykonywania zawodu jest ustanowiony w Konstytucji Rzeczypospolitej Polskiej zakaz łączenia mandatu posła

\footnotetext{
${ }^{50}$ Wyrok TK z dnia 7.05.2002 r., SK 20/00, Lex nr 54063.

${ }^{51}$ Wyrok WSA w Warszawie z dnia 14.06. 2016 r., VI SA/Wa 404/16, Lex nr 2159871.

${ }^{52}$ Wyrok TK z dnia 7.05.2002 r., SK 20/00, Lex nr 54063.

${ }^{53}$ Wyrok TK z dnia 19.04.2006 r., K 6/06, Lex nr 189582.
} 
i senatora z wskazanymi w art. 103 funkcjami państwowymi i zawodami oraz ustanowiony W art. 107 zakaz prowadzenia działalności gospodarczej z osiąganiem korzyści z majątku Skarbu Państwa lub samorządu terytorialnego. Zgodnie z § 9 Kodeksu Etyki Adwokackiej z zawodem adwokata nie wolno łączyć takich zajęć, które uwłaczałyby godności zawodu, ograniczałyby niezawisłość adwokata lub podważałyby zaufanie publiczne do Adwokatury. Jednym z przykładów uznawania za kolidujące z wykonywaniem zawodu adwokackiego jest zajmowanie w cudzym przedsiębiorstwie stanowiska zarządcy, sprawowanie funkcji członka zarządu, prokurenta w spółkach prawa handlowego oraz członka rady nadzorczej oddelegowanego do zarządu spółki prawa handlowego, chyba że jest to przejściowo sprawowana funkcja, mająca za cel wykonanie określonego i ograniczonego w czasie zlecenia klienta. Jak wynika z art. 4b Prawa o adwokaturze, adwokat, w przeciwieństwie do radcy prawnego, nie może być zatrudniony na podstawie umowy o pracę, przy czym zakaz ten nie dotyczy pracowników naukowych i naukowo-dydaktycznych ${ }^{54}$. Łączenie zawodów jest zabronione w przypadku wykonywania zawodu radcy prawnego i sędziego, asesora sądowego, prokuratora, notariusza, komornika, asesora prokuratorskiego i notarialnego bądź odbywania aplikacji sądowej, prokuratorskiej lub notarialnej (art. 26 ustawy o radcach prawnych $)^{55}$. Ograniczeniem zasady wolności pracy jest także zakaz podejmowania dodatkowego zatrudnienia. Przykładowo, jak wskazuje art. 103 Prawa o prokuraturze, prokurator nie może podejmować dodatkowego zatrudnienia, z wyjątkiem zatrudnienia na stanowisku dydaktycznym, naukowo-dydaktycznym lub naukowym. Ponadto prokurator ma obowiązek poinformować o zamiarze podjęcia dodatkowego zatrudnienia ${ }^{56}$. Z kolei zgodnie z art. 80 ustawy o służbie cywilnej członek korpusu służby cywilnej nie może podejmować dodatkowego zatrudnienia bez pisemnej zgody dyrektora generalnego urzędu ani wykonywać czynności lub zajęć sprzecznych z obowiązkami wynikającymi z ustawy lub podważających zaufanie do służby cywilnej. Zatrudnionego w służbie cywilnej obowiązują także inne ograniczenia dotyczące wymagań, które według art. 4 ustawy o służbie cywilnej taka osoba musi spełnić. W służbie cywilnej może być zatrudniona osoba, która jest obywatelem polskim, korzysta z pełni praw publicznych, jest niekarana za umyślne przestępstwo lub umyślne przestępstwo skarbowe, posiada kwalifikacje wymagane na dane stanowisko pracy oraz cieszy się nieposzlakowaną opinią ${ }^{57}$. Orzeczenie lekarskie w sprawie niezdolności do

\footnotetext{
${ }^{54}$ Tekst jedn.: Dz.U. z 2018 poz. 1184 ze zm.

${ }^{55}$ Tekst jedn.: Dz.U. z 2018 poz. 2115 ze zm.

${ }^{56}$ Tekst jedn.: Dz.U. z 2019 poz. 740.

${ }^{57}$ Tekst jedn.: Dz.U. z 2018 poz. 1559 ze zm.
} 
pracy także ogranicza wolność pracy (art. 12, 13 ustawy z 1998 r. o emeryturach i rentach z Funduszu Ubezpieczeń Społecznych $)^{58}$.

Zasada wolności pracy, jak już zostało wskazane, dotyczy także pracodawcy, któremu nie można nakazać nawiązania stosunku pracy. Od tej zasady istnieją jednak pewne wyjątki. Przykładem jest regulacja dotycząca ponownego zatrudnienia

Ponadto ograniczenie omawianej zasady znajduje się w art. 18 i 41 ustawy z dnia 29 maja 1974 r. o zaopatrzeniu inwalidów wojennych i wojskowych oraz ich rodzin ${ }^{59}$. Pracodawca, do którego inwalida wojenny lub wojskowy został skierowany przez starostę na wniosek tego inwalidy, jest obowiązany zatrudnić go stosownie do sprawności fizycznej i kwalifikacji zawodowych.

\section{Podsumowanie}

Jak już zostało wspomniane, praca odgrywa w życiu człowieka ogromną rolę - umożliwia zaspokajanie jego potrzeb, wpływa na pozycję jednostki w społeczeństwie, samorealizację i poczucie własnej wartości. Stąd niezwykle ważna jest odpowiednia, przemyślana regulacja dotycząca zasady wolności pracy. Mając to na uwadze, można uznać, że zasada ta jest jedną z najważniejszych zasad prawa pracy. Świadczą o tym także uregulowania konstytucyjne i kodeksowe tej zasady.

W tym miejscu trzeba zaznaczyć, że zasada wolności pracy doznaje licznych ograniczeń. Podkreślenia wymaga fakt, że ustawodawca konstytucyjny poddał wykonywanie zawodu ochronie jako "wolność". Oznacza to, iż wszelkie ograniczenia ustawowe wynikające z art. 31 ust. 3 Konstytucji RP muszą być interpretowane ściśle" ${ }^{60}$. Ustanawianie zbyt szerokich ograniczeń, interpretacja ich w sposób rozszerzający może prowadzić do negatywnych zjawisk, np. dyskryminacji ze względu na wiek. Ponadto w przypadku zakazu zajmowania określonego stanowiska, wykonywania określonego zawodu, brak jego precyzyjnego określenia, może doprowadzić do faktycznego pozbawienia możliwości podejmowania jakiejkolwiek aktywności zawodowej, co może skutkować całkowitym wykluczeniem skazanego z rynku pracy.

Ze względu na ilość ograniczeń należałoby się zastanowić, czy rzeczywiście można mówić o wolności pracy oraz czy istnieje potrzeba ustanawiania takich obostrzeń. Biorąc pod uwagę konsekwentne stanowisko Trybunału Konstytucyjnego, należy twierdząco

\footnotetext{
${ }^{58}$ Tekst jedn.: Dz.U. z 2018 poz. 1270 ze zm.

${ }^{59}$ Tekst jedn.: Dz.U. z 2017 poz. 2193 ze zm.

${ }^{60}$ Wyrok NSA z dnia 18.03.2009 r., II GSK 802/08, Lex nr 570324.
} 
odpowiedzieć na powyższe pytania. Istnieje potrzeba stworzenia ogólnych podstaw prawnych, wymagań, jakie należy spełnić, aby świadczyć wybraną przez siebie pracę. Ograniczenia zasady wolności pracy mają na celu gwarancję, że poszczególne funkcje społeczne będą wykonywane przez osoby należycie do nich przygotowane ${ }^{61}$. Ponadto w przypadku osób odbywających karę pozbawienia wolności należy zwrócić uwagę na szczególną rolę pracy. W oddziaływaniu na skazanych, $\mathrm{z}$ poszanowaniem ich praw i wymaganiem wypełnienia przez nich obowiązków, uwzględnia się przede wszystkim pracę, zwłaszcza sprzyjającą zdobywaniu odpowiednich kwalifikacji zawodowych (art. $67 \S 3$ Kodeksu karnego wykonawczego) ${ }^{62}$. Wydaje się, że właśnie przez obowiązek pracy osób odbywających karę pozbawienia wolności, możliwe jest zrealizowanie funkcji resocjalizacyjnej.

\section{Bibliografia:}

\section{Literatura}

Bejma U., Praca jako wartość w życiu człowieka. Wybrane aspekty, „Periodyk Naukowy Akademii Polonijnej" 2015, nr 4

Cudowski B., Dodatkowe zatrudnienie, Białystok 2007

Garlicki L., Konstytucja Rzeczpospolitej Polskiej. Komentarz, Warszawa 2016

Gersdorf M., Rączka K., Raczkowski M., Kodeks pracy. Komentarz, Warszawa 2011

Jan Paweł II, Przemówienie podczas 68 sesji Międzynarodowej Organizacji Pracy. Genewa 15 czerwca 1982, w: Dokumenty nauki społecznej Kościoła, cz. 2, Rzym - Lublin 1996

Kodeks pracy. Komentarz, red. A. Sobczyk, Warszawa 2018

Kuczma P., Konstytucyjna wolność pracy, „Przegląd Prawa i Administracji” 2016, CVII

Liszcz T., Prawo pracy, Warszawa 2018

Maciejko W., O wolności pracy i równości pracujących, „Praca i Zabezpieczenie Społeczne” 2005, $\mathrm{nr} 1$

Oleksa I., Praca jako wartość społeczna, „Scientific Bulletin of Chełm - Section of Pedagogy”, Chełm 2012

Prawo pracy, red. J. Stelina, Warszawa 2018

Sanetra W., Prawo pracy: Zarys wyktadu. Tom 1, Białystok 1994

Śledzińska-Simon A., Wolność pracy, w: Realizacja i ochrona konstytucyjnych wolności $i$ praw jednostki w polskim porzadku prawnym, Wrocław 2014

Zwoliński A., Praca i płaca jako temat nauczania Kościoła, „Studia Socialia Cracoviensia” 2013, nr 1

\section{Orzecznictwo}

Wyrok Trybunału Sprawiedliwości Unii Europejskiej z 15.11.2016 r. (C-258/15), Dz.U. C 14 z 16.1.2017

Wyrok Trybunału Sprawiedliwości Unii Europejskiej z dnia 13.12.2014 r. (C-416/13), Dz.U. C 16 z 19.1.2015

Wyrok Trybunału Sprawiedliwości Unii Europejskiej z dnia 12.01.2010 r. (C-229/08), Dz.U. C 63 z 13.3.2010.

\footnotetext{
${ }^{61}$ Wyrok TK z dnia 21.05.2002 r, K 30/01, Lex nr 54066.

${ }^{62}$ Tekst jedn.: Dz.U. z 2019 poz. 676 ze zm.
} 
Wyrok Trybunału Konstytucyjnego z 13.11.2012 r., K 2/12, OTK-A 2012, Nr 10, poz. 121, Lex nr 1227132

Wyrok TK z 23.02.2010 r., P 20/09, OTK-A 2010, Nr 34, poz. 191, Lex nr 559164

Wyrok TK z dnia 19.04.2006 r., K 6/06, Lex nr 189582

Wyrok TK z dnia 21.05.2002 r, K 30/01, Lex nr 54066

Wyrok TK z dnia 7.05.2002 r., SK 20/00, Lex nr 54063

Postanowienie TK z 09.04.2002 r., U 8/01, OTK-A 2001, Nr 2, poz. 25, Lex nr 54059

Wyrok TK z 13.06.2000 r., K 15/99, OTK 2000, Nr 5, poz. 137, Lex nr 41205

Wyrok TK z 19.10.1999, SK 4/99, OTK 1999, Nr 6, poz. 199, Lex nr 38260

Wyrok TK z 23.06.1999 r., K 30/98, OTK 1999, Nr 5, poz. 101, Lex nr 37396

Wyrok TK z 26.04.1999 r., K 33/98, OTK 1999, Nr 4, poz. 71, Lex nr 37316

Postanowienie SN z 6.09.2018 r., II PK 227/17, Lex nr 2549377

Wyrok SN z 12.04.2016 r., II PK 73/15, OSP 2017, Nr 6, poz. 17, Lex 2053636

Wyrok SN z 23.05.2014 r., II PK 273/13, Lex nr 1461235

Wyrok SN z dnia 24.10.2006 r., II PK 39/06, Lex nr 309389

Wyrok Sądu Apelacyjnego w Łodzi z 12.10.2018 r., III AUa 108/18, Lex nr 2612064

Wyrok Sądu Apelacyjnego w Poznaniu z 1.08.2018 r., III AUa 640/17, Lex nr 2550847

Wyrok Sądu Apelacyjnego w Katowicach z dnia 18.05.2017r., II AKa 88/17, Lex nr 2343405

Wyrok SA w Szczecinie z dnia 29.09.2016 r., III APa 2/16, Lex nr 2202540

Wyrok Sądu Apelacyjnego w Łodzi z dnia 27.11.2013 r., II AKa 65/13, Lex nr 1402878

Wyrok NSA z dnia 18.03.2009 r., II GSK 802/08, Lex nr 570324

Wyrok Naczelnego Sądu Administracyjnego z dnia 31.08.2006 r., OSK 1151/05, Lex 275441

Wyrok WSA w Warszawie z dnia 14.06. 2016 r., VI SA/Wa 404/16, Lex nr 2159871 